\title{
Lyrics in the Poetry of Ahmad Shawqi
}

\author{
Nada Yousuf Al-Rifai (2015) \\ College of Basic Education, PAAET, Kuwait.
}

Ahmad Shawqi (1868-1932) was one of the finest Arabic-language poets and dramatists to pioneer the modern Egyptian literary movement, most notable for introducing poetic epics to the Arabic literary tradition. Shawqi also produced distinctive poetry widely considered to be the most prominent of 20th century Egypt.

Shawqi, deemed the "Prince of Poets" and one of the greatest Arabic poets laureate, was raised in a privileged setting with Turkish, Kurdish, Circassian, Greek, and Arab roots. His family was prominent and well-connected with the court of the Khedive of Egypt. Upon graduating high school, Shawqi attended law school, obtaining a degree in translation. Shawqi was then offered a job in the court of the Khedive Abbas II, which he immediately accepted (Ahmad Shawqi Museum Site).

As Shawqi was very relevant to the Khedive Palace, the Khedive sent him in the late nineteenth century to France to continue his studies in law and learn about French literature at the Universities of Montpellier and Paris. While in France, he was heavily influenced by the works of French playwrights, most notably Molière and Racine. He remained in France for four years amid a climate of romance, symbolism, realism, and arts. There, he also got to know Francaise's comic theater and consequently wrote a play named "Ali Beck Al-Kabeer" (Ali Beck the Grand) in 1893 (Badawi, 2007).

Shawqi's work at the palace played a great role in facilitating ways of gaining information, knowledge, and access to European arts, as the Khedive sent him to Europe to learn about both French and English literature. He translated some literary works, such as Lamartine's poem, “The Lake." He was also impressed by Victor Hugo's historical poetry and looked over his collection of poems regarding great historical figures across the ages. Shawqi was also pleased by La Fontaine's poetry and fables. Thus, he was influenced by the French poets in their dealings with new subject matter, and their ways of forming their poems. He also took advantage of what he learned in France in choosing new topics; bringing them out in an innovative and exquisite manner; blending heritage with language, style, music, and imagination; and presenting them in a smooth Egyptian spirit, which fit the emerging Arab taste (Al-Sheikh, 2006).

He returned to Egypt in 1894, and remained a prominent member of Arab literary culture until the British forced him into exile in southern Spain, Andalusia, in 1914. Shawqi remained there until 1920, when he returned to Egypt. In 1927, he was crowned by his peers Amir al-Sho'araa' (literally, "the Prince of Poets") in recognition of his considerable contributions to the literary field (Ahmad Shawqi Museum Site).

Shawqi possessed a wonderful talent for versification and proved himself capable of composing long epic poems that incorporated the events of his time. He could also compose stanza systems and short poems of dynamic joy and appearance. (Al-Muqdad, 2006). 


\section{Music in His Poetry}

Dr. Shawqi Deif describes Ahmad Shawqi's outstanding talent with the following statement: "I do not exaggerate if I say that whenever I listen to a long poem of Shawqi, I feel as if I really listen to a symphony (Muneer Sultan, 1997, p. 44).

Ahmad Obeid quoted Anton Al-Jemeyil, who said:

The impact of the descriptive string is viewed in Shawqi's lyrical or chanting poetry, his love and courtship poetry, in his boyhood soliloquy, his smile to his children and grandchildren, his tear on his fathers and forefathers, and his free talks with his loved ones and close friends. Here lie the tenderness emotions and the anguish flaming, and here are the feeling palpitations and the heart pulses" (Al-Jemeyil, 1933, p. 362).

No people in the world manifest such enthusiastic admiration for literary expression and are so moved by the word, spoken or written, as the Arabs. Modern audiences in Baghdad, Damascus and Cairo can be stirred to the highest degree by the recital of poems, only vaguely comprehended, and by the delivery of orations in the classical tongue, though only partially understood. The rhythm, the rhyme and the music, produce on them the effect of what they call "lawful magic (sihr halal)" (Hitti, 1946, p. 90).

Carlyle, the famous British writer, says that everyone was created a poet, but the powers of poetry vary within him or her according to the strength of his or her emotions, eloquence, and surrounding influences. An Egyptian is surrounded by his or her civilization, nature, character, habits, and morals. Thousands of influences provoke one's soul, and evoke one's heart, but let us consider song in particular.

Nowadays, I do not know one Egyptian who is not thrilled by chants or whose mind is not captivated by a fine sound. Take any Egyptian and let him or her hear (ya layl) "O night," then look at him or her thrilled and drunk, twisting and swaying with the singer while singing, and dancing like a tambourine within the hand of its holder, shaking like a string beneath the Lutenist's feather. If even the average Egyptian, as you might have noticed, is deeply touched by the singing, how much more is the Egyptian poet? Shawqi was overjoyed by Abdu AlHamouli singing Abu Al-Hassan Al-Qayrawani's poem:

O lover's night, when is its tomorrow?

$$
\text { يا ليل الصب منى غده ؟ أقبام الساعة مو عده؟ }
$$

Is doomsday its date?

Consequently, Shawqi (1911) wrote these beautiful lines:

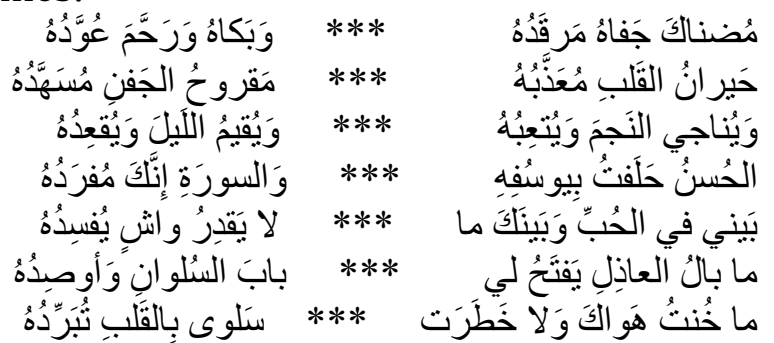

Your lover's bed rejected him

While his visitors cried farewell upon him.

His heart, confused and tormented

His eyelids sleeplessly ulcerated.

He talks to the star, tiring it 
Raising the night up and down.

I swear by the beauty of Yousuf, (the prophet)

And the (surrah) that you are beauty's single.

Between you and me, there is in love,

What a talebearer cannot spoil.

Why does the censurer open

The door of consolation, while I close it?

Never did I betray your love

Nor did a distraction occur to my heart to cool it down (Al Zohour, pp. 541-542).

\section{Lyric Poetry}

Shawqi composed the following lyric poem, "The Crescent," on his thirtieth birthday. Another year of his life had passed away; therefore, it was natural for him to look backward to see the outcome of this year, and how much he had accomplished during the past thirty.

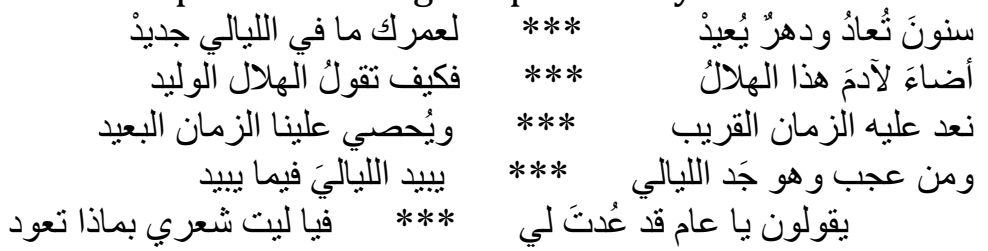

Years return, a returning age

There's nothing new within the nights.

This crescent lighted up for Adam

How come they call it the born crescent?

We count upon it the near time

While the far time counts upon us.

I wonder how while it's the nights' grandfather

It wipes up the nights, among what it wipes.

They say, oh year, you came back to me

I wish I could know what you came back with (Shawqi, “Al-Shawqidat," Part 2, p. 29).

One day, Shawqi invited the famous singer Umm Kulthum, who accepted the invitation and sang at "Karmat Ibn Hani" (Shawqi's house). In admiration of her singing, Shawqi gave her a glass of wine, but she would not drink alcohol. Thus, she acted tactfully and intelligently, raising the cup to her lips without actually sipping from it. Shawqi was impressed by her tact and wrote her a poem, which he delivered himself the next morning. The poem remained with her from 1932 to 1944, when she entrusted it to the famous composer Riad Al-Sunbati and sang it after changing the two lines which contained her name. (Al-Kilani, 2011).

Shawki said at the opening of the poem:

$$
\text { سلو ا كؤوس الطلا هل لامست فاها **** واستخبرو ا الر اح هل مسّت ثناياها }
$$

Ask the drizzled cups, did they touch her mouth?

And inquire the wine, did it contact her front teeth? (Sabry, 1979, Vol. II, p. 302). The poem was later on sung by her, composed by Riyad Al-Sunbaty. 
And among Shawqi's marvelous poems sung by the musician Mohammad Abdel Wahab, and later by the famous, soft-voiced, Lebanese singer Fairouz, is "O Neighbor of the Valley" (Ya Jarat Al-Wady), in which Shawqi said:
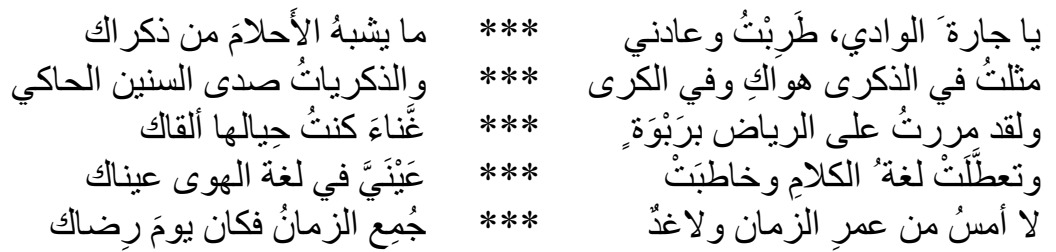

0 neighbor of the valley, I was enchanted and visited

By what looked like dreams of your remembrance.

I recalled your love in memory and in sleep

Since memories are the years' narrating echo.

I passed by the luxuriant gardens

Upon a hill, where I used to meet you.

The language of speech disrupted, while my eyes

Addressed your eyes in the language of love.

There is no yesterday in time, or tomorrow

All time collected to be the day of your gratification. (Shawqi, "Al-Shawqiyat,," II, p. 179).

Critics say that Shawqi lent a helping hand to Wahab. However, it is also true that Wahab lent one to Shawqi, helping him transcend the literary saloons and narrow forums and placing him on records widespread across the Arab world and later on the radio. This allowed his poetry to be heard by the general population.

An emotional and creative link existed between Shawqi and music and singing. He was a poet whose poems reflected the language of music, to the extent that it was said that he was born to be a musician but became a poet. Moreover, his psychological formation and openness to creative arts and aesthetics were well informed by Western cultures. (Khalaf, 2014).

At night when it was empty

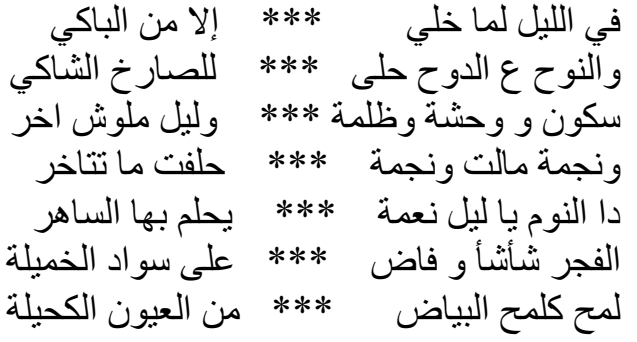

Except from the weeper.

Cooing on trees became pleasant

For the complaining crier.

Stillness, loneliness and darkness

In the endless night.

A star tended, and another

swore it won't be late. 
O night, sleep is a blessing

Wished by the wakeful.

Dawn rose and overflowed

Over the darkened grove.

It twinkled like the twinkling whiteness

Of the eyelined eyes. (Sabry, 1979, Vol. II, p. 306).

\section{Zajal (Colloquial Strophic Poetry)}

Shawqi cared for this type of art and composed zajal poems closer to the vernacular than to the classical Arabic, believing that to launch the songs out of the cheap vulgar sense into new meanings would transcend the feelings and lead to the achievement of an optimal aesthetic education (Mahmoud, 1961).

Shawqi loved Wahab to the extent that he wrote him special colloquial roles, songs, monologues, and many "Mawaweels" (roundelays). Shawqi would never abandon classical Arabic except to allow the voice of Wahab to star and his words to fly from his golden throat. (Anonymous, 2014).

In his own way, Wahab recognized Shawqi's greatness and, through his music, placed Shawqi into every Arabic house. Wahab's implicit recognition remained stronger than that of the poet Hafeth Ibrahim, and the other poets who led the speech on that historic day when Shawqi was deemed "The Prince of Poets." If these poets recognized "The Prince" by several poems, quickly preserved in books and forgotten, Wahab has placed Shawqi's words into every Arab home over nearly a whole century, and will continue to do this for many centuries to come.

\section{Words and Music}

It is possible, in a sense, to consider Shawqi as Abdel Wahab's poet, since he has especially written for him colloquial song poems like "Al-Neel Najashi" (The Nile is Negus), except that Shawqi initially wrote poetry as poetry and not as songs.

The Nile is Negus, nice and brownish

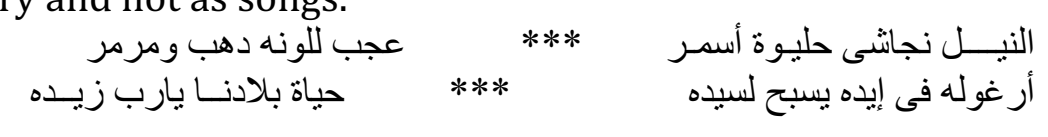

Its color is a wonder, gold and marble.

Its org within its hand, lauding its lord

The life of our country, 0 God increase it. (Fadil, 2006)

From among this poetry, Abdel Wahab chose and sang many poems, including "Operetta Qais and Leila" with Asmahan, "Mount Al-Towbad." "O Neighbor of the Valley," "I Am Antonio," and many other beautiful poems, which granted Abdel Wahab fame and immortality .

Umm Kulthum also sang some of Shawqi's immortal masterpieces like "Wuleda Al-Huda (The Guide Mohammad is Born)," "Reemun ala alqa (A White Antelope on the Plain)," "The Nile," "Salu ku'ous al-tela (Ask the Drizzled Cups)," and other poems never worn out by time. 


\section{Ahmad Shawqi and Children's Literature}

Upon his return from France, Shawqi started to lay the foundation for his children's literature. He explicitly announced this in the introduction of the first edition of his poetry collection "AlShawqiyat," which appeared in 1899 and included anecdotes, tales, and songs for children (Zalat, 1994).

Shawqi said, in the introduction of his first poetry collection "Al-Shawqiyat," "I wish that God would help me to make for the Egyptian children, as poets made for the children in civilized country; versifications which are closely affordable, throughout of which they take wisdom and literature to the best of their abilities" (Zalat, 1994, p. 103).

Shawqi included in the section "Specialties," in Part IV of his poetic collection "Al-Shawqiyyat," eleven poems about his three children, Ameena, Ali, and Hussein, most of which were dedicated to his daughter. The poems are the following: "Father of Ali," "The last time" "His Reign," "O Night," “Ameena," "A Playful Child," "Selfishness," “A Toy," "The Cradle's Beauty," "The First Step," and "The Day of His Parting" (Zalat, 1994, p. 113).

Shawqi's poetry collection "Al-Shawqiyat" includes several lovable children poems, including the following: "The Pussycat and Cleanliness," "Grandma," "My Homeland," "Being Kind to the Animal," "Mother," “The Raven's Son," “The Nile," "School," “The Egypt Anthem," and “Ode to the Scouts."

In his poem "A Playful Child," written for his daughter Ameena, he șaid:

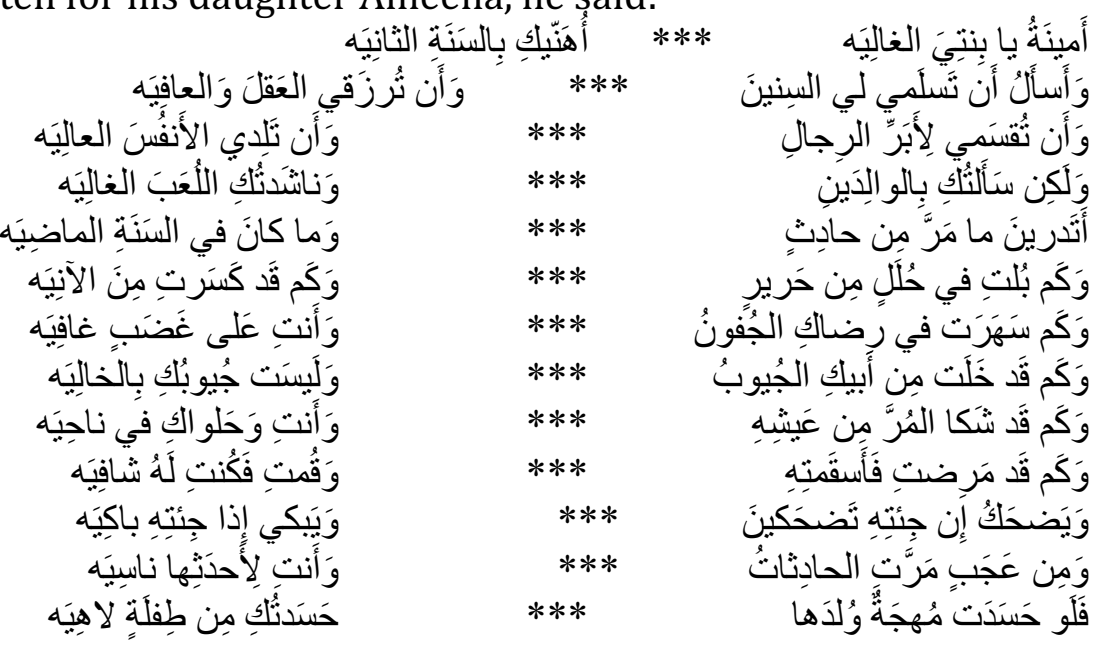

Ameena, my dear daughter,

I congratulate you on your second birthday.

I ask (God) that you remain well along the years,

And be granted with mind and good health.

That you be allotted to the best of men, giving birth to the lofty souls.

However I ask you by your parents, And request you by your precious toys.

Did you know what passed of incidents, And what happened in the past year? 
How often you pissed in silk dresses,

How many plates you have broken?

How many a times, eyelids remained sleepless to please you,

While you slept angrily.

How many a times, your dad's pockets were emptied,

While yours weren't.

How many a times, he complained of livelihood bitterness,

While you were busy with your candies.

How many a times, you got sick hence ailed him,

Then cured him when you recovered.

He laughs when you come laughing to him,

And cries when you come crying.

How wonder the events have passed by,

while you forgot about them.

If there were ever a heart to envy its child,

I would envy you, my flimsy child. (Shawqi, "Al-Shawqiyat," IV, p. 98).

Among the poems which Shawqi wrote about early childhood was his poem "The School Friends," in which he portrayed the memories of his childhood in a brilliant way that summarized the daily events with his peers at the "Maktab" or "Kuttab" (elementary school), stating:

How pleasant was the school's companionship,

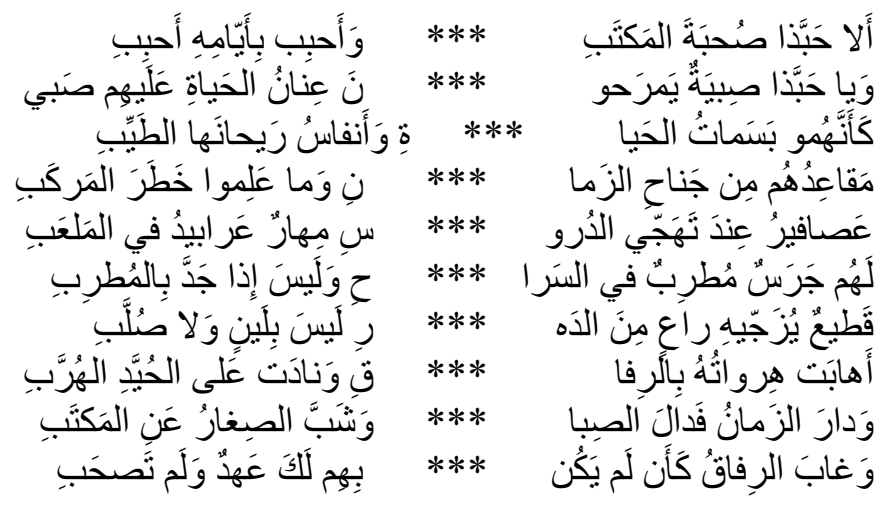

How lovely were those days.

How nice were the playful boys,

Life's rein was young on them.

They were life's smiles,

And its good smelling breath.

Seated on the age's wing,

They never knew the vehicle's risk.

Birds when they spell lessons, 
Skillful rompers in the pitch.

The bell amused them upon release,

Yet didn't when it called for seriousness.

A flock shoved by its shepherd, Neither gently nor harshly.

His cudgel frightened the gentle,

And called on the deviating escapers.

Age turned around, youth was over,

The youngsters grew up, finished school.

The comrades left as if there were no

Acquaintance among us, or companionship. (Shawqi, “Al-Shawqiyat,” II, p. 147).

\section{His Poetic Language}

Dr. Shawqi Daif said "poetry and singing united in Shawqi, and everything in him prepared him for that, as he was an admirer of singing and singers on the one hand, while his poetry had a magical musical sweetness on the other hand ... There is no doubt that this had an effect on Shawqi's poetry, not in terms of authorship of the songs, but also in terms of selecting the words. Shawqi did not mean in his songs to amuse himself only and his singer, but also intended to please the mass audience and this aim, which Shawqi was unable to get rid of, made him descend from the high sky of his eloquent words, which he usually elected in his poems, into easy words that would go on every tongue." (Zalat, 1994).

The "Nile" chant is among the songs that received the most publicity and recognition from the audience of children and adults alike, and was sung by school children in festivals and celebrations. In this poem, Shawqi simply and plainly describes the Nile River and its beauty, saying:

The fresh Nile is the "Kawthar"*,
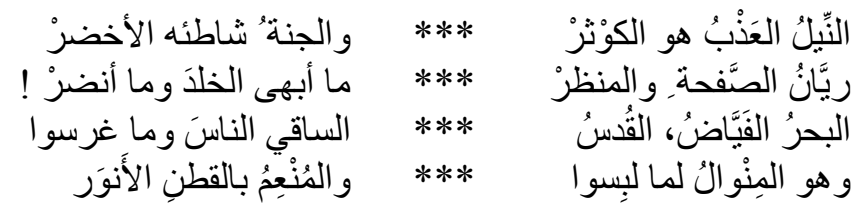

And its green beach is paradise.

Its surface is sated, as well as its view,

How gorgeous and blooming heaven is.

The profluent sea,

The holy watering to people and what they instilled

Making them obtain what they wear,

Granting the brightest cotton. (Shawqi, "Al-Shawqiyat," IV, 195):

*

Kawthar: the name of a river in paradise.

The most important patriotic song written by Shawqi was "The National Anthem of Egypt." This anthem not only addressed children through its content, but also went beyond them to 
other sections of the nation during an important period of time during which a national consciousness emerged among the Egyptians after the 1919 revolution. In 1921, his "Nasheed Masr" won the first prize in the national competition for songs, and when Sayed Darwish melodized it, it was sung by people in every faction in the nation (Zalat, 1994):

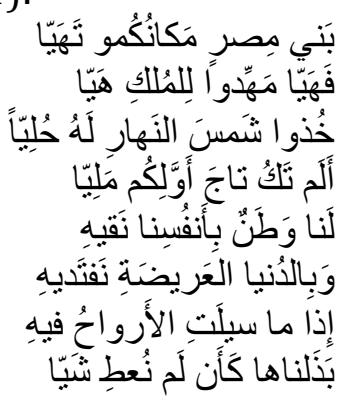

Sons of Egypt your place is well arranged,

So go ahead and pave for kingdom.

Take the day's sun as a jewelry,

Wasn't it your first's crown?

We have a homeland that we protect with our selves,

And sacrifice broad life for it.

If souls were to flow in it,

We would sacrifice them as if we gave nothing. (Shawqi, “Al-Shawqiyat,” IV, 197).

Shawqi wrote nearly a dozen poems and around thirty poetry stories on the tongues of animals, as did the French poet La Fontaine. Among the poetry that Shawqi wrote for children is his poem about the pussycat, in which he said:
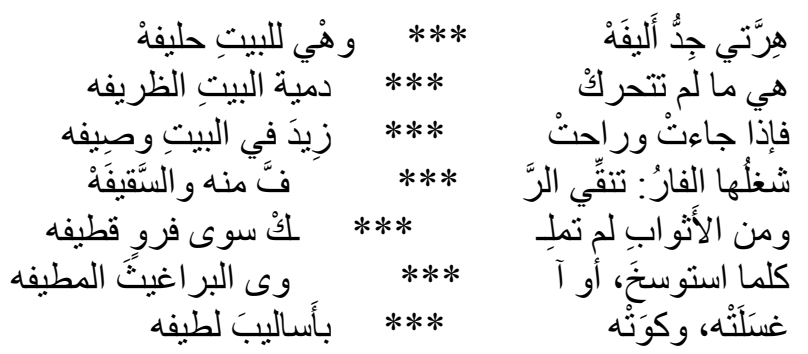

My cat is really tame,

She's the home's ally.

As long as she doesn't move,

She's the home's cute doll.

When she comes and goes,

She adds a maid to the house.

The mouse is her business,

Clearing up the rack and the penthouse.

As for dresses, she only

Owns a velvet fur.

Whenever it gets dirty,

or harbors roving fleas. 
She washes and irons it, In nice manners.

And from the cat, we move on to the grandmother in the poems which Shawqi dedicated for children. He says about his grandmother:

I have a grandma who pities me,
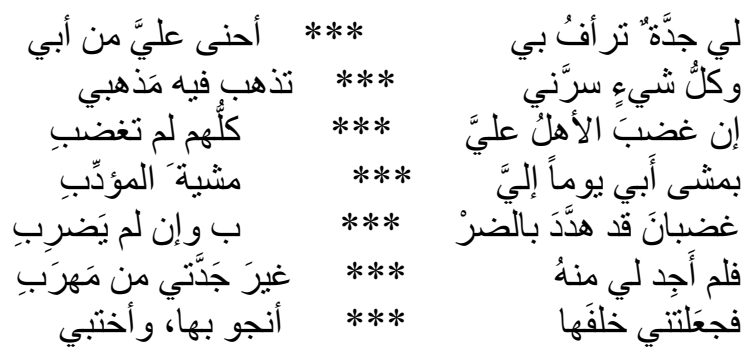

She is kinder to me than my Dad.

In everything that pleases me,

She follows my doctrine.

She wouldn't get angry even if

All the family got angry with me.

Once my dad got on his feet,

To discipline me

Huffy, threatening to hit me,

Though he did not.

I did not find a shelter from him,

Except my grandmother

She kept me behind her,

My rescue and refuge. (Shabloul, 2011).

Shawqi also composed poetic stories on the tongue of the animals in an easy and attractive manner. He narrated 56 of those tales, the first of which was published in the newspaper AlAhram in 1892, and was entitled "Al-Deek Al-Hindi wa Al-Dajaj Al-Baladi (The Indian Rooster and the Local Chicken)," and symbolized the occupying forces and Egypt. (Hashim, 2013)

Musician Abdul Wahab said:

Shawqi used to travel for more than one reason. As an artist he liked to cohabit things and live with them, cohabiting the country, cohabiting the neighborhood, and cohabiting the room. When we used to go to the hotel, the hotel owner would give him the same room which he gave to him when he was a student in Paris, and would give him the chair which he used to sit on. He used to sit in a café named "Darnor ," so whenever he entered they knew him, and emptied his familiar site for him and his own table.

He loved to read in French because he graduated from the Sorbonne, therefore he liked reading everything about the books he was working on. For instance, when he wanted to write "Cleopatra," he traveled to Paris, and bought all the books that talked about Cleopatra in order to know who is Cleopatra in the eyes of the foreigners, what she meant to them and how they looked at her. (Wahab, S. A. (2006) p. 50). 
Shawqi was not only Egypt's poet and its "Prince of Poets", but he was also the head of that emirate in all the Arab countries. There is no student, school or university in Egypt or in any other Arab country, which ignored his verses that remained among us as eternal proverbs.

$$
\text { و إنما الأمم الأخلاق ما بقيت فإن هم ذهبت أخلاقهم ذهبو المان }
$$

Nations are but ethics, as long as they remain,

If their morals are gone, thus are they; gone.

\section{References}

Ahmad Shawqi Museum Site, http://www.ashawkymuseum.gov.eg/7ayatoh.html.

Al-Jemeyil, A. (1933). In Memory of the Two Poets, Damascus, Syria: Al-Maktaba Al-Arabia.

Al-Kilani, F. N. (2011). Encyclopedia of Arab Poets. Diyala, Iraq: Balad Ruz.

Al-Muqdad, M. (translator) (2006). "Al-Elham wa fan Al-She'r enda Ameer Al-Shu'ara Ahmad Shawqi,," Kuwait: The Foundation of Abdulaziz Saud Al-Babtain's Prize for Poetic Creativity. Original book: Boudot-Lamotte, A. (1977). Ahmad Shawqi: L'homme et l'oeuvre. France: Institut Francais de Damas.

Al-Sheikh, H. (2006), “Jadalliyat Al-Turath fe She'r Shawqi Al-Ghina'ie,” Al-Maktab Al-Jami'e Al-Hadeeth, Alexandria, Egypt.

Anonymous (2014, August 18). Shawqi and Abdul Wahab: a large school... and one pupil! Kuwait Magazine 370.

Anonymous (1911, February 1). Ahmad Shawqi. Al-Zohour, 1(12), 541-542.

Badawi, A. (2007). Derasat fe Al-Nass Al-She'ry Al-Hadeeth. Cairo, Egypt: Dar Qubaa'.

Fadil. J. (2006). Abdul Wahab paid allegiance Shawqi as the prince of poetry. Al-Arabi, 567.

Hashim, M. A. (2013, September 14) “Fi Mada'in alf layla wa Layla," (In the towns of One Thousand and One Nights), Kuwait Magazine 358.

Hitti, P. K. (1946). History of the Arabs (3rd ed.). London: Macmillan.

Khalaf, A. (2014, July 18). Ahmad Shawqi wa Thaqafat Asrein (Ahmad Shawqi and the culture of two eras). AlWatan, p. 19.

Mahmoud, M. H. (1961). Ma'a Shawqi. Cairo, Egypt: al-Dār al-Qawmīyah lil-Ṭibā'ah wa-al-Nashr.

Muneer Sultan (1997). Al-Badee'fe She'r Shawqi, Alexandria, Egypt: Matba'at Sami.

Sabry, M. (1979). Al-Shawqiyat Al-Majhoula (2nd ed.): Beirut, Lebano:. Dar Al-Massara.

Shabloul, A. F. (2011 March). Ameer Al-Shu'ara baina jadaty wa Qittaty (The Prince of poet between his cat and his grandma).Al-Arabi Al-Sagheer, 222.

Shawqi, A. (n.d.). Al-Shawqiyat. Dar Al-Ketab Al-Arabi: Beirut, Lebanon.

Wahab, S. A. (2006), Shawqi fi Oyoun Mu'asereh (Shawqi in the eyes of his contemporaries). Kuwait: The Foundation of Abdulaziz Saud Al-Babtain's Prize for Poetic Creativity.

Zalat, A. (1994). Children's Literature between Ahmad Shawqi and Othman Gala. Al-Wafa library, Al-Mansoura, Egypt: Publishing House of Egyptian Universities. 